Summer 2010

\title{
Germany's Basic Law and the Use of Force
}

Russell A. Miller

Washington \& Lee School of Law

Follow this and additional works at: https://www.repository.law.indiana.edu/ijgls

Part of the Comparative and Foreign Law Commons, European Law Commons, and the International Law Commons

\section{Recommended Citation}

Miller, Russell A. (2010) "Germany's Basic Law and the Use of Force," Indiana Journal of Global Legal Studies: Vol. 17 : Iss. 2 , Article 3.

Available at: https://www.repository.law.indiana.edu/ijgls/vol17/iss2/3

This Symposium is brought to you for free and open access by the Law School Journals at Digital Repository @ Maurer Law. It has been accepted for inclusion in Indiana Journal of Global Legal Studies by an authorized editor of Digital Repository @ Maurer Law. For more information, please contact rvaughan@indiana.edu.

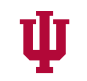

JEROME HALL LAW LIBRARY INDIANA UNIVERSITY Maurer School of Law
Blooming ton 


\title{
Germany's Basic Law and the Use of Force
}

\author{
RUSSELl A. MILLER*
}

\begin{abstract}
The German Basic Law's Regime for the use of force is evidence of and an explanation for the deep difference between Germany and the United States on security matters. It also might say something more grand about the power of law to constrain force.
\end{abstract}

\section{INTRODUCTION}

Among the German Basic Law's (Grundgesetz or constitution) distinguishing features, and in light of its considerable success, there is one thread in its remarkable tapestry that particularly merits further attention. It is a matter of constitutional law with singular significance for transatlantic affairs and is therefore especially worthy of recognition in a "German-American Dialogue on NATO's 60th Anniversary."

Six decades after the founding of NATO, scholars are still debating the roles that the United States and Germany should play in securing the two nations' shared interests. On this issue there has been disagreement and disappointment on both sides of the Atlantic, with the United States generally pressing for the projection of force, and Germany balking. These roles were popularly caricatured by Robert Kagan in his essay Of Paradise and Power, which he published in an earlier and more strained part of this decade. ${ }^{1}$ Back then Kagan invoked

* Associate Professor of Law, Washington \& Lee University School of Law; CoEditor-in-Chief, German Law Journal (http://www.germanlawjournal.com); Co-author, with Donald Kommers, of a treatise on German constitutional law. See DONALD P. KOMMERS \& RUSSEll A. MILleR, THE CONSTITUTIONAL JURISPRUDENCE OF THE FEDERAL REPUBLIC OF GERMANY (3rd ed. forthcoming 2011). This essay was completed during my tenure as a Fulbright Senior Scholar at the Max Planck Institute for Comparative Public Law and Public International Law, Heidelberg, Germany (2009-10). Email: millerra@wlu.edu.

1. Robert Kagan, Of Paradise and Power (2003). For a number of critiques of Kagan's claims, see the German Law Journal symposium issue "New Transatlantic Tensions and the Kagan Phenomenon." Articles of particular relevance include Rebecca M.

Indiana Journal of Global Legal Studies Vol. $17 \# 2$ (Summer 2010)

(c) Indiana University Maurer School of Law

DOI: 10.2979/GLS.2010.17.2.197 
a tired cliché from pop-psychology and declared that, "on major strategic and international questions today, Americans are from Mars and Europeans are from Venus."2 More recently, the headlines that followed President Barack Obama's visit to Baden-Baden as part of the state conference marking the sixtieth anniversary of NATO suggested that, on the question of security, the United States and Germany are playing to type. "Europeans offer few new troops for Afghanistan," the New York Times trumpeted. "Mr. Obama has been greeted warmly on a personal level," the report said, "but his calls for a more lasting European troop increase for Afghanistan were politely brushed aside."3 President Obama should not take this as a personal slight. After all, one of the more entertaining moments in Oliver Stone's otherwise unremarkable movie, W., depicted the forty-third President railing against "that kraut Schröder" because Chancellor Schröder had refused to lead Germany into the "coalition of the willing" that was being formed to execute Operation Iraqi Freedom. ${ }^{4}$

From a perspective informed by German constitutional jurisprudence, this essay addresses this confounding facet of GermanAmerican relations, which is central to the viability and efficacy of NATO today. It argues that modern Germany's deeply embedded reticence toward the use of force, which consistently places it in conflict with America's more muscular vision of trans-Atlanticism, has both roots and expression in the Basic Law. It concludes by suggesting that Germany's constitutional use-of-force regime does more than provide insight into U.S. and German differences on matters of security, but that the German constitution might have achieved something more grand with its challenge to the persistent realist argument that force cannot be constrained by law.

\section{THE BASIC LAW AND THE USE OF FORCE}

The German people are distinctly keyed to law. It should come as no surprise, therefore, that an examination of Germany's security policy

Bratspies, This Too Shall Pass: A Response to Kagan's Power and Weakness, 4 GERMAN L.J. 879 (2003); Olaf Dilling, If I Had a Hammer - A Review of Kagan's Power and Weakness, 4 GERMAN L.J. 963 (2003); Russell Miller, The Shared-Transatlantic Jurisprudence of Dignity, 4 GERMAN L.J. 925 (2003); Andreas Paulus, Antimonies of Power and Law: A Comment on Robert Kagan, 4 GERMAN L.J. 871 (2003). These articles are available at http://www.germanlawjournal.com/index.php?pageID=2\&vol $=4 \& n o=9$.

2. KAGAN, supra note 1 , at 3 .

3. Steven Erlanger \& Helene Cooper, Europeans Offer Few New Troops for Afghanistan, N.Y. TIMES, Apr. 5, 2009, at A6.

4. Tim Harper, W's Already Old in an Era that Deems Yesterday Historic, TORONTO STAR, Oct. 18, 2008, available at http://www.thestar.com/World/Columnist/article/519763. 
also might effectively begin with the law. The Roman historian Tacitus remarked that Rome learned more from the northern Germanic tribes than from any of the other barbarians on the messy margin of the Empire. He singled out the Germans' well-developed system of customary law for praise. It was offset, perhaps, by their quirky insistence on appearing at any gathering fully armed and by an awkward penchant for blurting out everything on their mind straight away. ${ }^{5}$ Others have remarked that while the French were storming the Bastille, the Germans were busy establishing administrative law courts. Of course, even the terror of the Holocaust was framed and fueled by what formalistically passed as law. ${ }^{6}$

With the National Socialist history in mind, the framers of the Basic Law insisted on a "peace constitution." The preamble declares that in promulgating a new constitution the Germans were "inspired by the determination to promote world peace as an equal partner in a united Europe."7 Further evidence of the Basic Law's inherent pacifism can be found in Article 1(2), providing that "the German people . . . acknowledge inviolable and inalienable human rights as the basis of every community, of peace and of justice in the world." Article 9(2), one of the Basic Law's remarkable "militant democracy" provisions, permits the prohibition of associations whose aims or activities are directed "against . . . the concept of international understanding."9 Article 26(1) renders unconstitutional and obliges the German government to criminalize "acts tending to and undertaken with intent to disturb the peaceful relations between nations, especially to prepare for a war of aggression."10 To be sure, there are competing clauses that might be interpreted as "hints" that German rearmament was inevitable.11 However, the Constitutional Court did not get the chance to choose

5. See Steven OzMent, A Mighty Fortress: A New History of the German PEOPLE 22 (2004).

6. See, e.g., ABraham J. Edelheit \& Hershel Edelheit, History of THE HOLOCAUST: A HANDBOOK AND DICTIONARY 299-331 (1994) (listing, by country and chronologically, the national socialist legislation passed). But see Gustav Radbruch, Gesetzliches Unrecht und übergesetzliches Recht [Statutory Lawlessness and Suprastatutory Law], 1 SÜDDEUTSCHE JURISTEN-ZEITUNG [S. GERMAN L.J.] 105 (1946) (raising the possibility of "statutory lawlessness" and "supra-statutory law" in reaction to Nazi "law").

7. GRUNDGESETZ FÜR DIE BUNDERESPUBLIK DEUTSCHLAND [GG] [Basic Law] May 23, 1949 , pmbl.

8. Id. art. $1, \S 2$.

9. Id. art. $9, \S 2$.

10. Id. art. $26, \S 1$.

11. Uwe Wesel, Der Gang Nach Karlsruhe: Das Bundesverfassungsgericht in DER GESCHICHTE DER BUNDESREPUBLIK [THE ROAD TO KaRLSRUHE: THE FEDERAL CONSTITUTIONAL COURT IN THE HISTORY OF THE FEDERAL REPUBLIC] 73-75 (2004). 
between these interpretive possibilities. Chancellor Konrad Adenauer's earliest attempt to rearm West Germany was cut short when France withdrew from plans to create a European Defense Community, thereby rendering moot the case before the Constitutional Court that raised these fundamental constitutional questions about Germany's security profile. ${ }^{12}$

Nonetheless, the strict pacifist elements of the original Basic Law were soon overshadowed by constitutional amendments pushed through by Adenauer's super-majority government in $1954 .{ }^{13}$ These amendments, particularly implicating Article 79(1), paved the way for West Germany's NATO membership and remilitarization by making it easier for Germany to commit to international security institutions and regimes. ${ }^{14}$ Yet the constitutional provisions that facilitated Germany's rearmament did just as much to entrench Germany's post-war reticence for the use of force. Article 87(a), for example, empowered the newly formed federal armed forces to defend Germany and to be deployed "only to the extent expressly permitted by this Basic Law."15 Thus, even as Germany rearmed and integrated into the Western security framework, its constitutional law would dictate and define the function of the armed forces.

Through the long years of the Cold War a number of social and political factors combined to cement the consensus that the German armed forces were to be used exclusively for the purpose of defending NATO territory. Surely, the ever-present memories of German atrocities and suffering in the Second World War hardened the pacifist sentiment evident in the Basic Law and expressed in the defense consensus that prevailed during the Cold War. Additionally, the constitutional provision that guarantees the right to object to military service as a matter of conscience contributed to widespread pacifist sentiment.

12. Id.

13. Id. See also Gesetz zur Ergänzung des Grundgesetzes [Law for the Amendment of the Basic Law], Mar. 26, 1954, BGBl. I art. 45a.

14. Protocol to the North Atlantic Treaty on the Accession of the Federal Republic of Germany, Oct. 23, 1956, 6 U.S.T. 5707, 243 U.N.T.S. 308. Article 79(1) of the Basic Law was amended to read: "This Basic Law may be amended only by a law expressly amending or supplementing its text. In the case of an international treaty regarding a peace settlement, the preparation of a peace settlement, or the phasing out of an occupation regime, or designed to promote the defense of the Federal Republic, it shall be sufficient, for the purpose of making clear that the provisions of this Basic Law do not preclude the conclusion and entry into force of the treaty, to add language to the Basic Law that merely makes this clarification." GRUNDGESETZ FÜR DIE BUNDERESPUBLIK DEUTSCHLAND [GG] [Basic Law] May 23, 1949, art. 79(1), translated by German Bundestag Public Relations Division (Christian Tomuschat, David P. Currie \& Donald P. Kommers trans., 2008).

15. GRUNDGESETZ FÜR DIE BUNDERESPUBLIK DEUTSCHLAND [GG] [Basic Law] May 23, 1949, art. 87a. 
Increasing numbers of young German men sought to avoid conscription by invoking this provision. ${ }^{16}$ To stem this tide the government required conscientious objectors to appear before local committees to defend their views. Many Germans' pacifist views were galvanized by these proceedings. In any case, the zero-sum implications of armed confrontation along the hot German front of the Cold War made it a logical imperative that "for over forty years, the [leadership of the Federal Republic of Germany] interpreted the Basic Law to mean that German military forces could only be used for defensive purposes on North Atlantic Treaty Organization (NATO) territory."17 Considering the Cold War stalemate in Europe, this was as good as saying the German armed forces might never be deployed.

German reunification, together with the increasing distance in time since the end of the Second World War, came to pose a rather significant challenge to the constitutional consensus that Germany's armed forces could be used only for defense of the NATO territory. Germany's "68er" Chancellor, Gerhard Schröder, tactfully but resolutely advocated a "normal" role for the Federal Republic in world affairs. ${ }^{18}$ This included, as its chief goal, the ongoing quixotic German pursuit of a permanent seat on the U.N. Security Council, a body dominated by states possessed of the military wherewithal to ensure the world's peace and security. ${ }^{19}$ Starting in the early 1990s, Germany-to show its willingness to flex its muscle -increasingly began to deploy its armed forces for purposes other than the defense of German or NATO territory. ${ }^{20}$

16. Id. art. $4, \S 3$.

17. Walter J. Lemanski, Note, The Reemergence of German Arms: How Far Will Germany's March Toward Full Use of Military Force Go?, 29 VAND. J. TRANSNAT'L L. 857, 859 (1996).

18. The term "68er" refers to the generation of Germans who precipitated, participated in, and grew up in the shadow of the counter-culture student movement that flared into violent protests in Germany (as elsewhere in the world) in 1968. See 1968 IN EUROPE (Martin Klimke \& Joachim Scharloth eds., 2008); MARTIN KLIMKE, THE OTHER ALIIANCE: StUdent Protest IN West Germany aNd the UNITEd States IN THE Global SiXties (2009).

19. See, e.g., Germany Starts U.N. Reform Resolution, DW.WoRLd.DE, May 17, 2005, http://www.dw-world.de/dw/article/0,,1585795,00.html; German U.N. Aspirations Backed by Europe, DW.WORLD.DE, Sept. 24, 2004, http://www.dw-world.de/dw/article/

0,,1337830,00.html; Germany Seeks U.N. Veto Parity, DW-WoRLD.DE, Dec. 12, 2004, http://www.dw-world.de/dw/article/0,,1422951,00.html; U.N. Reform Targets Security Council, DW-WORLD.DE, Dec. 2, 2004, http://www.dw-world.de/dw/article/ $0,1413668,00 . \mathrm{html}$.

20. See Georg Nolte, Germany: Ensuring Political Legitimacy for the Use of Military Forces by Requiring Constitutional Accountability, in DEMOCRATIC ACCOUNTABILITY AND THE USE OF FORCE IN INTERNATTONAL LAW 231, 234-35 (Charlotte Ku \& Harold K. Jacobson eds., 2002). 
The first of these ventures involved support of NATO and U.N. peace-making or humanitarian efforts in Bosnia-Herzegovina, Somalia, and Serbia-Montenegro. A constitutional challenge to these nondefensive deployments ended with the Constitutional Court handing the federal government a Pyrrhic victory. In the AWACS I Case from 1994, the Court upheld the constitutionality of the challenged deployments. ${ }^{21}$ However, in doing so it articulated constitutional principles that greatly constrain Germany's use of force. Decades after the Adenauer government proposed such an interpretation, the Court held in AWACS $I$ that Article 24(2) of the Basic Law impliedly authorized the government to fulfill its obligations under treaties like the U.N. Charter and the North Atlantic Alliance, including the deployment of armed forces. $^{22}$ Yet the Court went on to hold that any deployment of the German armed forces for non-defensive purposes requires prior parliamentary approval. ${ }^{23}$ The Court could not point to a clear textual basis for this significant constitutional limitation on the use of force. ${ }^{24}$ Instead, it derived the rule from constitutional history, pointing to the Weimar-era requirement for a parliamentary declaration of war or peace. ${ }^{25}$ The Court also referred to the Basic Law's assignment of the military's budget to the parliament. ${ }^{26}$ The Court further explained that the rule existed as an echo of parliament's constitutional prerogative over treaty making in the first instance, a prerogative that is revived when obligations under a treaty call for dramatic measures like troop deployments. ${ }^{27}$ The Court concluded by underscoring that the rule reinforced the ever-fragile balance between almost plenary executive authority in foreign affairs and the principle of checks and balances inherent in the separation of powers. ${ }^{28}$

In the last decade the Court slightly relaxed this constitutional limitation on Germany's use of force.$^{29}$ In 2001, for example, the Court turned aside constitutional challenges to the federal government's

21. Bundesverfassungsgericht [BVerfG] [Federal Constitutional Court] July 12, 1994, 90 Entscheidungen des Bundesverfassungsgerichts [BVerfGE] 286 (F.R.G.).

22. Id.

23. Id.

24. Id.

25. Id.

26. BVerfGE $90,286$.

27. Id.

28. Id.

29. See, e.g., Bundesverfassungsgericht [BVerfG] [Federal Constitutional Court] Mar. 12, 2007, 117 Entscheidungen des Bundesverfassungsgerichts [BVerfGE] 359 (F.R.G.); Bundesverfassungsgericht [BVerfG] [Federal Constitutional Court] May 22, 2001, 104

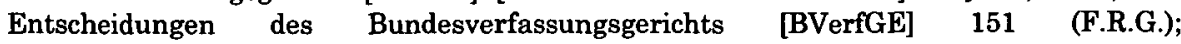
Bundesverfassungsgericht [BVerfG] [Federal Constitutional Court] Mar. 25, 1999, 100 Entscheidungen des Bundesverfassungsgerichts [BVerfGE] 266 (F.R.G.). 
accession to NATO's new, out-of-territory, and non-defensive "strategic concept." 30 The radical military implications for Germany's participation in the new "strategic concept" were obvious. At the time the new "strategic concept" was announced in 1999, the alliance was executing its bombing campaign against Serbia, an action that was neither defensive nor concerned with NATO territory. ${ }^{31}$ In spite of the firm assertion of parliamentary priority in AWACS $I$, and without regard to the very evident military implications, the Court was untroubled by the fact that the federal government had committed Germany to NATO's new "strategic concept" without consulting the parliament. ${ }^{32}$ The Court's decision in the NATO Strategic Concept Case probably was foreshadowed by its earlier decision finding nothing constitutionally objectionable about the deployment of German armed forces in support of NATO's Kosovo campaign. ${ }^{33}$ Later, the Constitutional Court approved of the parliament's general and open-ended authorization of force deployments in support of NATO's ongoing Afghanistan operation. ${ }^{34}$

With the AWACS II Case, decided in 2008, the Court put an end to this trend and firmly reasserted the rule from $A W A C S I .^{35}$ In spite of his strident opposition to President George W. Bush's Iraq "adventure," Chancellor Schröder nonetheless planned to send German AWACS planes to Turkey, which summoned NATO backing in anticipation of a flailing, aggressive gesture from Saddam Hussein's threatened regime. ${ }^{36}$ The Chancellor argued that parliamentary approval, consistent with the rule from AWACS I, was not needed in this instance because the AWACS aircraft were serving strictly defensive purposes within the framework of Germany's NATO obligations. ${ }^{37}$ The Constitutional Court disagreed and ruled Schröder's deployment of the aircraft to Turkey a constitutional violation. ${ }^{38}$ It is a mandate of the Basic Law's separation of powers, the Court firmly reiterated, that the parliament alone has the constitutional authority to decide on deployments to armed conflicts. ${ }^{39}$ This is especially true, the Court explained, in light of the political dynamics of an alliance system. Germany should not be led into armed

\footnotetext{
30. BVerfGE 104, 151.

31. Id.

32. Id.

33. BVerfGE $100,266$.

34. BVerfGE 117, 359.

35. Bundesverfassungsgericht [BVerfG] [Federal Constitutional Court] May 7, 2008, 121 Entscheidungen des Bundesverfassungsgerichts [BVerfGE] 135 (F.R.G).

36. See Richard Bernstein, Threats and Responses: The Alliance; Germany Says NATO Rift Over Turkey Is Near an End, N.Y. TMES, Feb. 14, 2003, at A14.

37. BVerfGE 121, 135.

38. Id.

39. Id.
} 
conflict by foreign interests framed as collective security concerns; deployments must be authorized by the Federation's popularly elected branch. ${ }^{40}$ Significantly, the Court found a parliamentary presumption in the relevant constitutional framework. When in doubt, the Court explained, parliament has priority with respect to the deployment of the German armed forces. ${ }^{41}$ This rule, reaffirmed in AWACS II, has led most scholars to accept that the German armed forces are properly described as a Parlamentsarmee-a Parliamentary Army. ${ }^{42}$ This presents a very real, systemic constraint on Germany's projection of force. If anyone doubts this, it is only necessary to recall that Chancellor Schröder had to package his 2001 Afghanistan troop deployment, meant to support America's immediate post-9/11 campaign against the Taliban, with a no-confidence vote. ${ }^{43} \mathrm{He}$ barely survived-with a mere two-vote cushion-to see Germany join the American-led Operation Enduring Freedom. ${ }^{44}$

A final, very significant constitutional limitation on Germany's use of force, which has silently operated to make the preceding discussion of Constitutional Court jurisprudence possible, is the fact that the Basic Law clearly gives the Constitutional Court jurisdiction to hear challenges to the federal government's plans to deploy the armed forces. ${ }^{45}$ The Constitutional Court does not observe a political question doctrine. ${ }^{46}$ Instead, the Court repeatedly has been called upon to judge the constitutionality of the federal government's security agenda. The Court in AWACS II emphasized this important feature of the constitutional regime limiting Germany's use of force by clearly reiterating that these questions are subject to full judicial review. ${ }^{47}$

The Basic Law's regime regarding the use of force, in its substance but also in the Constitutional Court's clear jurisdiction over such matters, is both evidence of and an explanation for the German reticence toward the use of force that often frustrates American

40. Id.

41. Id.

42. Id.; see also Dr. Angela Merkel, Chancellor F.R.G., Germany's Foreign and Security Policy in the Face of Global Challenges, Speech at the 42nd Munich Conference on Security Policy (Feb. 4, 2006), http://www.securityconference.de/archive/konferenzen/ rede.php?menu_2006=\&menu_konferenzen $=\&$ sprache $=$ en $\& i d=170 \&$.

43. Steven Erlanger, Pressing Greens, German Leader Wins Historic Vote on Sending Troops to Afghanistan, N.Y. TTMES, Nov. 17, 2001, at A10.

44. Id.

45. GRUNDGESETZ FÜR DIE BUNDERESPUBLIK DEUTSCHLAND [GG] [Basic Law] May 23, 1949 , art. $93, \S 1$, sentence 1 .

46. David P. CurRie, The Constitution of the Federal Republic of Germany 4445 (1994).

47. BVerfGE 121, 135. 
policymakers. The frustration on the American side of the Atlantic might be understandable considering that the U.S. Constitution has posed nothing similar to the German limitations on the executive branch's discretion to embroil the nation in armed conflict. The texts of the U.S. Constitution and the Basic Law do not definitively answer the question of the competence, and limits thereon, to use force. But unlike the German case, the interpretation of the U.S. Constitution's assignment of war making authority, at least in practice, has heavily favored the President, to Congress's disadvantage. Direct attempts by Congress to "fulfill the intent of the framers . . . and ensure that the collective judgment of both the Congress and the President will apply to the introduction of United States Armed Forces into hostilities," have failed.48 In the United States the armed forces are anything but a parliamentary army. And the courts, hiding behind the political question doctrine, have generally refused to intervene to bring the President to heel.

More than Kagan's banal "Mars" and "Venus," 49 it is better to note, especially on the occasion of the Basic Law's sixtieth anniversary, that distinct constitutional regimes giving force to distinct constitutional values explain the American and German differences in transatlantic security policy.

\section{CONCLUSION: THE BASIC LAW LAYING REALISM TO REST?}

On the occasion of the Basic Law's sixtieth anniversary, perhaps one might hazard a grander and more normative claim for its use-of-force regime. More than a mere doctrinal and cultural phenomenon that explains differences in German and American security policy, is it possible that the Basic Law's contribution to curbing Germany's significant militarist tradition provides rare evidence for the hope that force can be constrained by law?

We know well the realism that dominates U.S. international law and international relations theory and practice. This realism is, ironically, largely attributable to the influence of German immigrants like Hans Kelsen, Leo Strauss, and Hans J. Morgenthau to the United States. At the core of these theorists' contributions is the Machiavellian/Hobbesian worldview that humankind is self-interested

48. War Powers Resolution, 50 U.S.C. $\$ \S 1541-1548$ (1991). See generally HAROLD HongJU KOH, THE NATIONAL SECURITY ConstituTION: SHARING POWER AFTER THE IRANCONTRA AFFAIR (1990); JOHN HART ELY, WAR AND RESPONSIBILITY: CONSTITUTIONAL

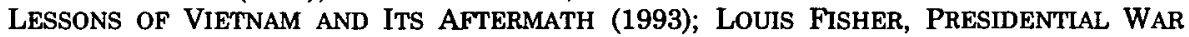
POWER (1995).

49. KAGAN, supra note 1. 
and brutish; might, not law, is what counts. Their views find voice today in the United States through the neo-conservative commentary and policy positions of the already-mentioned Robert Kagan, as well as through Michael Glennon, Eric Posner, Jack Goldsmith, John Yoo, John Bellinger, Josh Bolton, and Paul Wolfowitz. Perhaps the experiences of the last half-decade have adequately cast their fundamentalist and formalistic realism into doubt. But the narrative offered in this essay provides its own, perhaps deeper, repudiation. When it comes to force, the law is far from dead. ${ }^{50}$ To the contrary, the Basic Law has made the use of force in Germany almost exclusively a question of democracy and law. The Basic Law has given Germany a new kind of army, unraveling a bellicose German militarism with roots in Tacitus' era (and earlier) and that resonated across the centuries as "an important part of the self-understanding of the majority of Germans." 51

Joachim Käppner recently noted that postwar Germany seized, "for the first time in the country's history, the chance to reconcile the German military with German democracy." 52 This, Käppner concluded, "is one of the great success stories of the Federal Republic." 53 If this is so, and if the world is lucky and wise enough to learn from this remarkable German example, then this reconciliation of military and democracy will have to count equally as one of the great successes of the German Basic Law. That would be good reason indeed to celebrate the Bonner Grundgesetz.

50. See Michael J. Glennon, Why the Security Council Failed, FoREIGN AFF., May-June 2003, at $16,16-36$.

51. Kurt Kister, Der zivile Reserveoffizier [Civilian Reserve Officer], SüDDEuTschE ZEITUNG, (F.R.G.), May 4, 2009, available at http://www.sueddeutsche.de/politik/ 706/467280/text/.

52. Joachim Käppner, Der alte Geist zog nicht mehr ein [The Old Spirit Is No Longer Moved], SÜDDEUTSCHE ZEITUNG (F.R.G.), May 4, 2009, available at http://www.sueddeutsche.de/politik/658/467233/text/.

53. Id. 